\title{
Changes in Water Levels and Storage in the High Plains Aquifer, Predevelopment to 2005
}

\section{—By V.L. McGuire}

The High Plains aquifer underlies 111.4 million acres $(174,000$ square miles) in parts of eight States-Colorado, Kansas, Nebraska, New Mexico, Oklahoma, South Dakota, Texas, and Wyoming. The area overlying the High Plains aquifer is one of the major agricultural regions in the world. Waterlevel declines began in parts of the High Plains aquifer soon after the beginning of extensive ground-water irrigation. By 1980, water levels in the High Plains aquifer in parts of Texas, Oklahoma, and southwestern Kansas had declined more than 100 feet (Luckey and others, 1981). In response to these water-level declines, the U.S. Geological Survey (USGS), in cooperation with numerous Federal, State, and local waterresources agencies, began monitoring more than 7,000 wells in 1988 to assess annual water-level change in the aquifer. A report by the USGS, "Water-Level Changes in the High Plains Aquifer, Predevelopment to 2005 and 2003 to 2005" (McGuire, 2007), shows the areas of substantial water-level changes in the aquifer from the time prior to substantial ground-water irrigation development (predevelopment or about 1950) to 2005 (fig. 1).

In parts of the area, farmers began using ground water for irrigation extensively in the 1930s and 1940s. Estimated irrigated acreage in the area overlying the High Plains aquifer increased rapidly from 1940 to 1980 and changed slightly from 1980 to 2002: 1949-2.1 million acres, 1980 - 13.7 million acres, 1997-13.9 million acres, 200212.7 million acres. Irrigated acres in 2002 were 12 percent of the aquifer area, not including the areas with little or no saturated thickness (McGuire, 2007).

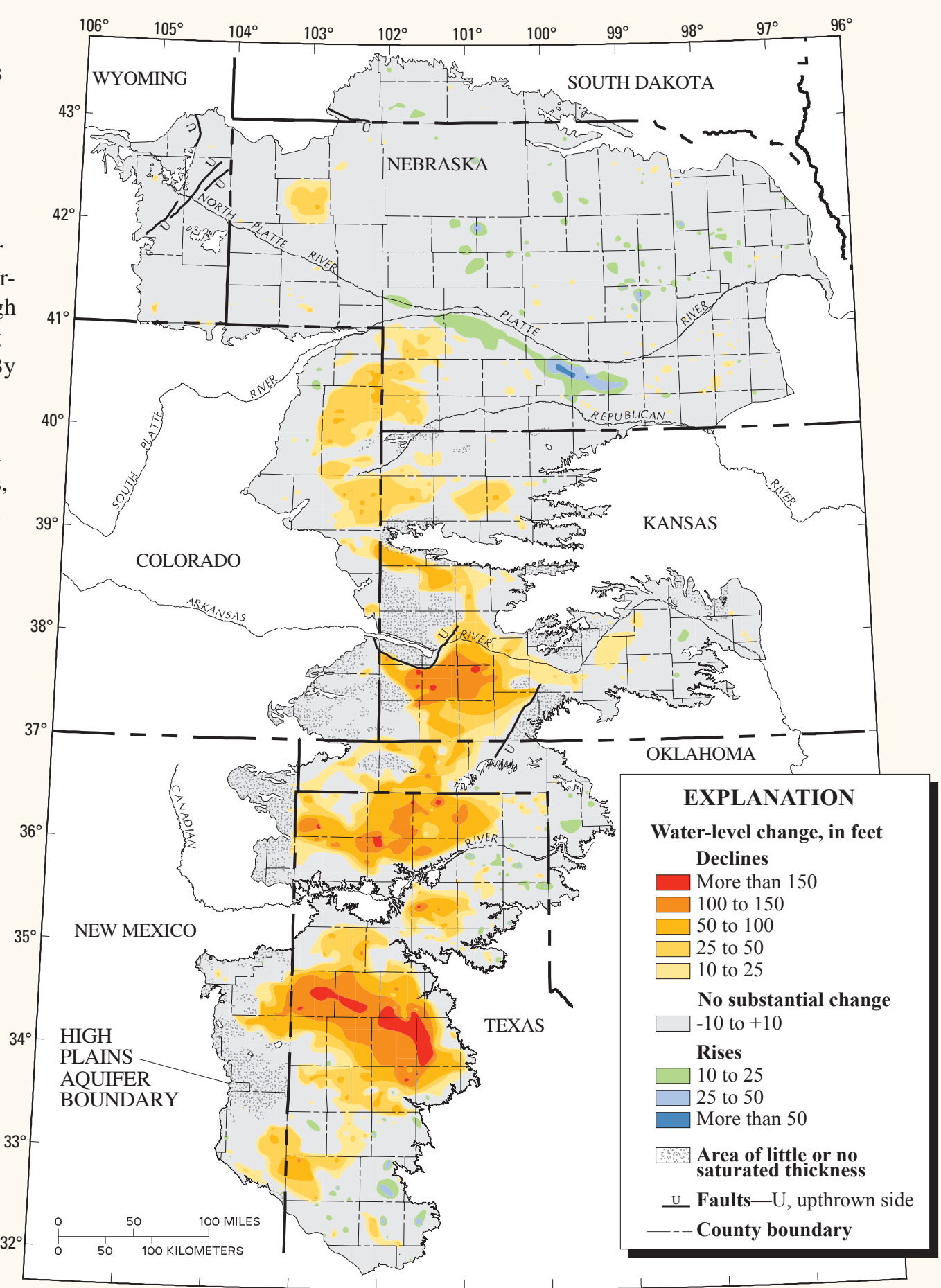

Base from U.S. Geological Survey digital data, 1:2,000,000 Standard parallels $29^{\circ} 30^{\prime}$ and $45^{\circ} 30^{\prime}$, central meridian $-101^{\circ}$

Figure 1. Water-level changes in the High Plains aquifer, predevelopment to 2005 (modified from McGuire, 2007). 
Ground-water withdrawals for irrigation and other uses are compiled and reported by the USGS and agencies in each State about every 5 years. Ground-water withdrawals from the High Plains aquifer for irrigation increased from 4 to 19 million acre-feet from 1949 to 1974 . Ground-water withdrawals for irrigation in 1980, 1985, 1990, and 1995 were from 4 to 18 percent less than withdrawals for irrigation in 1974. Ground-water withdrawals from the aquifer for irrigation in 2000 were 21 million acre-feet (McGuire, 2007).

Water-level changes in the aquifer result from an imbalance between discharge and recharge. Discharge is primarily ground-water withdrawals for irrigation. Discharge also includes evapotranspiration, where the water table is near the land surface, and seepage to streams and springs, where the water table intersects with the land surface. Recharge is primarily from precipitation. Other sources of recharge are irrigation return flow and seepage from streams, canals, and reservoirs. Water-level declines may result in increased costs for groundwater withdrawals because of increased pumping lift and decreased well yields (Taylor and Alley, 2001). Water-level declines also can affect ground-water availability, surface-water flow, and near-stream (riparian) habitat areas (Alley and others, 1999).

\section{Water-Level Changes, Predevelopment to 2005}

The map of water-level changes in the High Plains aquifer from predevelopment to 2005 (fig. 1) was generated using methods described by McGuire (2007). The map is based on water levels from 3,682 wells, which were measured in predevelopment and in 2005, and other previously published data in areas with few predevelopment water levels. The areas with few predevelopment water levels are in the central part of the Nebraska Panhandle, west-central Nebraska, and southeastern Wyoming.

The water-level changes from predevelopment to 2005 ranged between a rise of 84 feet and a decline of 277 feet. Area-weighted, average water-level change from predevelopment to 2005 was a decline of 12.8 feet. Approximately 25 percent of the aquifer area had more than 10 feet of waterlevel decline from predevelopment to $2005 ; 17$ percent had more than 25 feet of water-level decline, and 9 percent had more than 50 feet of water-level decline. Approximately 2 percent of the aquifer area had more than 10 feet of waterlevel rise from predevelopment to 2005 (McGuire, 2007).

\section{Change in Water in Storage, Predevelopment to 2005}

Total water in storage in 2005 was about 2,925 million acre-feet, which was a decline of about 253 million acre-feet (or 9 percent) since predevelopment. Water in storage for predevelopment was inferred from water in storage in 2000 and water-level changes from predevelopment to 2000. Changes in storage prior to predevelopment were not estimated (McGuire, 2007).

\section{References Cited}

Alley, W.M., Reilly, T.E., and Franke, O.L., 1999, Sustainability of ground-water resources: U.S. Geological Survey Circular 1186, 78 p., accessed March 22, 2007, at http:// pubs.usgs.gov/circ/circ1186/

Luckey, R.R., Gutentag, E.D., and Weeks, J.B., 1981, Waterlevel and saturated-thickness changes, predevelopment to 1980, in the High Plains aquifer in parts of Colorado, Kansas, Nebraska, New Mexico, Oklahoma, South Dakota, Texas, and Wyoming: U.S. Geological Survey Hydrologic Investigations Atlas HA-652, 2 sheets, scale 1:2,500,000, accessed March 22, 2007, at http://pubs.er.usgs.gov/ usgspubs/ha/ha652

McGuire, V.L., 2007, Water-level changes in the High Plains aquifer, predevelopment to 2005 and 2003 to 2005: U.S. Geological Survey Scientific Investigations Report 2006-5324, 7 p., accessed March 22, 2007, at http://pubs. usgs.gov/sir/2006/5324/

Taylor, C.J., and Alley, W.M., 2001, Ground-water-level monitoring and the importance of long-term waterlevel data: U.S. Geological Survey Circular 1217, 68 p., accessed March 22, 2007, at http://pubs.usgs.gov/circ/ circ1217/

\section{Acknowledgments}

The water-level data used in this report were provided by the following agencies_Colorado: State Engineer's Office; Kansas: Department of Agriculture-Division of Water Resources and Kansas Geological Survey; Nebraska: Central Nebraska Public Power and Irrigation District, Natural Resources Districts, and University of Nebraska-Lincoln, Conservation and Survey Division; New Mexico: Office of the State Engineer; Oklahoma: Water Resources Board; South Dakota: Department of Environment and Natural Resources; Texas: Water Development Board and Groundwater Conservation Districts; Wyoming: State Engineer's Office; and Federal: Bureau of Reclamation, U.S. Fish and Wildlife Service, and U.S. Geological Survey offices in Colorado, Kansas, Nebraska, New Mexico, Oklahoma, South Dakota, Texas, and Wyoming.

\section{For More Information}

Contact: Director

USGS Nebraska Water Science Center 5231 South 19th Street

Lincoln, NE 68512

(402) 328-4100

Copies of this fact sheet may be obtained from: U.S. Geological Survey, Information Services,

Box 25286, Denver Federal Center, Denver, CO 80225. 